\title{
Regional Management of Areas with Indications of Urban Sprawl in the Surrounding Areas of Universitas Muhammadiyah, Yogya- karta, Indonesia
}

\author{
Sri Rum Giyasih
}

Received: 09022017 / Accepted: 2104 2016 / Published online: 30062017

(C) 2017 Faculty of Geography UGM and The Indonesian Geographers Association

\begin{abstract}
This research was conducted in the surrounding areas of a university, Universitas Muhammadiyah Yogyakarta (UMY), which is administratively located in Tamantiro Village, Kasihan District, Bantul Regency, the Special Region of Yogyakarta, Indonesia. It aims to formulate the regional management of the surrounding areas as they have been presenting the indications of urban sprawl. It used a qualitative method with research data obtained from in-depth interviews to 22 informants including governmental agencies ( 7 informants), academics (6 informants), entrepreneurs (5 informants), and villagers ( 4 informants). The informants were sampled using purposive sampling method. Data processing and analysis were conducted using qualitative descriptive method, i.e. (1) data reduction, (2) data presentation, and (3) data conclusion. Data validation and reliability tests were conducted using source triangulation method. The results show that the stakeholders proposed various management strategies to improve the positive impacts and, at the same time, reduce the negative impacts of urban sprawl. These management strategies include (1) consistency in implementing spatial planning regulation, (2) spatial synergism in development planning, implementation, and monitoring, (3) assistance to the native people and the migrants, and (4) integration between the university and the village.
\end{abstract}

Keywords: areas around UMY, indications of urban sprawl, outskirts, regional management.

\begin{abstract}
Abstrak Penelitian ini dilakukan di kawasan sekitar Kampus UMY yang secara administratif termasuk di dalam Desa Tamantirto, Kecamatan Kasihan, Kabupaten Bantul, Provinsi Daerah Istimewa Yogyakarta, Indonesia. Penelitian ini bertujuan untuk merumuskan pengelolaan wilayah di sekitar Kampus UMY yang mengalami gejala urban sprawl. Penelitian ini menggunakan metode kualitatif. Teknik pengumpulan data dilakukan dengan cara wawancara mendalam kepada 22 informan yang terdiri dari unsur pemerintah (7 informan), akademisi (6 informan), pelaku usaha (5 informan), dan masyarakat umum (4 informan). Pengambilan sampel informan dilakukan dengan metode purposive samping. Metode pengolahan dan analisis data dilakukan secara deskriptif kualitatif dengan cara: (1)reduksi data, (2)penyajian data, dan (3)penarikan kesimpulan. Metode uji validitas dan reliabilitas data dilakukan dengan metode trianggulasi. Adapun metode trianggulasi yang digunakan adalah triangulasi sumber. Hasil penelitian menunjukkan bahwa dalam rangka untuk meningkatkan dampak positif serta untuk mengurangi dampak negatif gejala urban sprawl maka para stakeholders mengusulkan untuk: (1)konsisten dalam melaksanakan aturan penataan ruang, (2)sinergisme spasial dalam perencanaan, pelaksanaan, dan pemantauan pembangunan, (3) pembinaan kepada penduduk baik penduduk asli maupun penduduk pendatang, dan (4) integrasi kampus dan kampung.
\end{abstract}

Kata kunci: gejala urban sprawl, kawasan sekitar kampus UMY, pengelolaan wilayah, pinggiran kota.

\section{Introduction}

This research defines the indications of urban sprawl as the outward spreading of urban physical features [Brian, 2016; Morote and Hernandez, 2016]. These indications are part of urban expansion [Oeslati et al., 2015; Dadi et al.,2016; Ewing, et al.,2017]. Spatially, they present in three spatial patterns, namely: (1) concentric or low-density continuous development, (2) ribbon/linear/axial development, and (3) leapfrog or checkerboard development. Concentric development involves the slowest spreading of urban area among the other signs of urban sprawl. It spreads slowly depending on

Sri Rum Giyasih

Faculty of Geography, Universitas Gadjah Mada, Indonesia Correspondent e-mail: rum_ugm@yahoo.co.uk the outer part of urban physical feature. [Woltjer, 2014; Wei and Knox, 2015; Winarso et al.,2015; Shatkin, 2016]. The role of transportation is thereby less significant in this type of urban sprawl.

Linear development shows uneven spreading to the outer side of a city. This type of urban expansion spreads rapidly along the transportation lines. In other words, areas along the transportation lines receive the heaviest pressure from population growth and the expansion of urban functions because they offer the highest degree of physical accessibility [Kiggundu, 2014; Nazarnia, et al., 2016; Osman et al., 2016; Setyono, dkk, 2016; Weilermann et al., 2017].

Meanwhile, leapfrog development represents a sporadically dispersed spreading that usually grows in the middle of productive agricultural land. This type of urban sprawl brings the most harmful to ecology 
[Anjarsariningtyas et al., 2016; Dupras et al., 2016] because it disrupts vegetation coverage that functions as the lungs of the outskirts and maintains the stability of microclimate. Furthermore, it also causes immediate negative impacts on agricultural activities due to the encroachment of productive and technically irrigated agricultural lands [Harini et al, 2014; Sriartha and Giyarsih, 2015; Sudrajat, 2016]. On one side, the encroachment reduces the extent of available agricultural land. On the other side, it also leads to further disruptions to agricultural land, for example, to the performance of irrigation channel [Yunus, 2008; Giyarsih, 2010; Giyarsih, 2012; Giyarsih, 2014].

In term of physical dimension, urban sprawl can be identified using three indicators, namely: (1) land use characteristics, (2) building characteristics, and (3) circulation characteristics [Smiles, 1985, in Yunus, 2008; Surya, 2016]. Smiles [1985] further explained that urban land use is characterized by the predominance of built-up area (building coverage) over vegetation coverage. As for building characteristics, an area is deemed experiencing urban sprawl when the existing buildings are in high density and are functioned majorly for urban activities. In addition, an area is classified to having experienced urban sprawl when its circulation is characterized by a high transportation network density.

In term of non-physical dimension, urban sprawl is indicated by the outward spreading of urban socioeconomic nature. An area is categorized as experiencing urban sprawl when its livelihood structure shows a change, i.e. the number of farmers decreases or, in other words, the number of people working in industrial and service sector increases [Giyarsih and Alfana, 2013], or when the behavior of its people changes from rural to urban behavior. The behavioral change includes, for example, a transition from communal society (paguyuban/ gemeinschaft), which is commonly found in a rural life, to associational society (patembayatan/gesselschaft).

A communal society does not prioritize material values in interpersonal relationships; it relies on kinships. Meanwhile, in associational society, material values become the benchmark of conducting life, i.e. as the orientation of the society. The initially strong kinship in a rural area has been fading due to the introduction of new life values that emphasize more on formal interpersonal relationship [Yunus, 2008].

The aforementioned description postulates that the outskirts of Yogyakarta have been experiencing regional transformation. Nowadays, the outskirts are experiencing rapid population growth and economic development [Giyarsih and Alfana, 2013; Skog and Stelnnes, 2016]. This phenomenon is found around Universitas Muhammadiyah Yogyakarta (UMY), which is administratively located in Tamantirto Village, Kasihan District, Bantul Regency, the Special Region of Yogyakarta, Indonesia. The urban sprawl occurring around the university shows specific spatial pattern and process that inevitably bring various positive and negative consequences to the other surrounding areas.

Following this background, the research aims to formulate the regional management of areas around UMY that have been presenting indications of urban sprawl. The results expectedly offer both academic benefits and empirical-practical benefits. From academic point of view, this research contributes to scientific development especially in the field of urban geography. Meanwhile, from empirical-practical perspective, this research contributes to the development of the thinking pattern of related stakeholders in formulating regional development policy.

\section{The Methods}

This research was conducted in areas surrounding UMY, i.e. a university located administratively in Tamantiro Village, Kasihan District, Bantul Regency (see Figure 1). These areas were selected as a research site because they have been presenting the indications of urban sprawl, as characterized by their physical and socioeconomic growth. This qualitative research obtained data from indepth interviews to 22 informants including governmental agencies (7 informants), academics (6 informants), entrepreneurs (5 informants), and villagers (4 informants). The informants were sampled using purposive sampling method. Meanwhile, the informants in each of these categories were sampled using snowball sampling technique. The size of samples in this snowball technique was not determined initially; however, the snowball stopped when the sampled informants in each category provided repeated (saturated) answers [Sugiyono, 2007]. Then, the research data was processed and analyzed in three steps, as stated by Moleong [2005], namely data reduction, data presentation, and data conclusion. Data analysis was conducted not only after data collection but also since the first step of data collection and throughout the research. Every data collection was immediately followed by data processing and analysis. Data validation and reliability tests were conducted using source triangulation method, i.e. crosschecking informants.

\section{Result and Discussion}

The results of in-depth interviews to several stakeholders show that the indications of urban sprawl occurring in areas around the university have introduced both positive and negative impacts on various dimensions of life. In order to maintain and improve the positive impacts as well as reduce the negative impacts, the stakeholders proposed: (1) consistency in implementing spatial planning regulation, (2) spatial synergism in development planning, implementation, and monitoring, (3) assistance to the native people and the migrants, and (4) integration between the university and the village. The following 


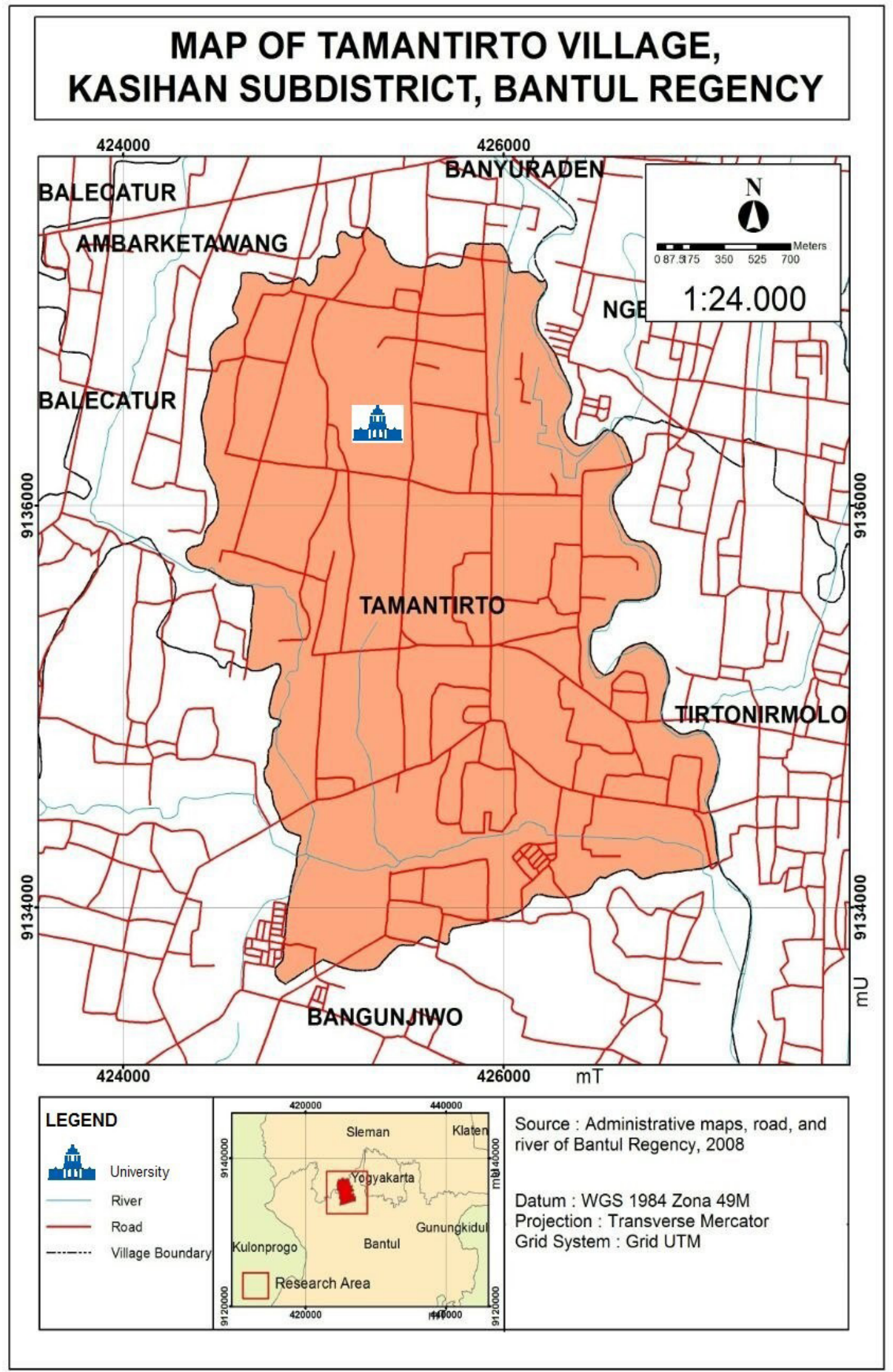

Figure 1. Administrative Map of Tamantirto Village 
subchapters describe these four regional management strategies in areas with indications of urban sprawl.

\section{Consistency in Implementing Spatial Planning Regulation}

The physical indications of urban sprawl are characterized by the conversion of agricultural to non-agricultural land. Before the indications of urban sprawl exist in an area, the land use is predominated by vegetation coverage. However, urban sprawl causes the predominant land use to change from vegetation coverage to building coverage or built-up area. Massive agricultural to non-agricultural land conversion occurring around the university brings negative consequences, for example, to food security system both around the university and in a wider regional constellation. On one side, this land conversion reduces the extent of agricultural land; on the other side, it disrupts the remaining agricultural land, as stated by one of the informants. "The [harvest] result from thepastand presentagriculture is different. It used to be more. The harvest used to be up to 13 sacks. But now, after the construction of many buildings close to my rice field, the harvest is only 10 sacks. The cause is, well, the irrigation channel does not work well. Also, my rice field is borderd by buildings. My rice field, of course, receives less sunshine." (Interview to V1/informant from villagers on August 19, 2016)

This research found that the indications of urban sprawl have brought negative consequences to the conversion of agricultural to non-agricultural land as well as to food security. These findings are in line with Brookfield et al., [1991] and Sriartha and Giyarsih [2015]. Unless there are no strategies to decelerate the agricultural land conversion in areas around the university, the remaining agriculturalland will eventually disappear. This finding is in line with Yunus [2001], Harini [2012], Sutaryono [2012], Sudrajat [2016], and Tian et al. [2017]. One of the strategies proposed by the stakeholders to solve this problem is by implementing the spatial planning regulation consistently.

It is no longer a secret that the documents of spatial planning (Spatial Planning or Detailed Spatial Area Plans) in several areas in Indonesia are only stored in the bookshelves after their issuance by the representatives of related regencies/cities and provinces. Bantul Regency issued the Local Regulation No. 04 in 2011 on the Spatial Planning of Bantul Regency in 2010-2030. This document regulates the location of agricultural land permitted/prohibited to be converted to non-agricultural land. Nowadays, the Government of Bantul Regency strictly implements the regulation on the prohibition of agricultural land conversion on the green belt. Some areas around the university are part of a green belt. An interview to the following informant shows that land conversion is difficult to decelerate. "[Some areas in] Tamantirto are part of a green belt, for example, the west part of Ngebel Hamlet. [The rice fields located in the] green belt are not allowed to be drained.

"Some of the villagers in this area tried to drain their rice fields, which are located on the green belt, but the process, of course, stopped in the National Land Agency (Badan Pertanahan Nasional-BPN)." (Interview to G1/ informant from government agencies, on August 2, 2016)

"Not every rice field is allowed to be drained. The rice fields located on the green belt are not allowed to be drained, for example, in the west part of Ngebel Hamlet." (Interview to G2/informant from government agencies, on August 19, 2016).

These interviews prove that the agricultural land draining in Bantul Regency is very difficult to proceed. The process starts after the Office of Public Works, Bantul Regency issues a permission letter for land conversion. This letter is then proposed to the National Land Agency of Bantul Regency for verification. If this agricultural land is not located on the green belt, the next process will be field observation. On the contrary, if the land is part of the green belt, the conversion proposal will be rejected directly by the National Land Agency of Bantul Regency. This process is part of the strategy applied by the Government of Bantul Regency to maintain the food security in related areas.

Empirically, there are indeed violations to this regulation. This research found that the draining prohibition is violated because field observations showed that rice fields located on the green belt were converted into buildings, as explained by the following interview.

"Here, some areas are part of the green belt. Many people asked for draining permission to me, but I refused them and, then, I asked them to directly propose to the Government of Bantul Regency. They said that the proposal for draining permission was rejected, but they kept building the land anyway. I cannot disallow them because the situation always turns back to me, they asked me whether I can provide them a piece of land for their houses. So, what should I do then?" (Interview to G3/informat from government agencies, on August 3, 2016)

The results of these interviews show that the conversion process of agricultural to non-agricultural land on the green belt is very limited. The Government of Bantul Regency has produced a regulation to protect fertile, productive, and technically irrigated agricultural land. The regulation is the Circular Letter of the Regent No. 648/02283 on May 22, 2015 on the Housing Development Control in Kasihan, Banguntapan, Sewon, Bantul, and Pleret District, which lasts until December 31, 2016. This circular letter is expected to be able to control the agricultural to non-agricultural land conversion, as explained by the following interview. "The Government of Bantul Regency produced a decree that contains a moratorium on housing development permission aimed to construction developers; [this 
moratorium] lasts until December 31, 2016. [The decree is for] Sewon, Kasihan, Banguntapan, Pleret, and Bantul District." (Interview to G4/informant from government agencies on August 11, 2016)

\section{Spatial Synergism in Development Planning, Implementation, and Monitoring}

According to Yunus [2008], spatial synergism is a strategy to integrate several areas so that the final products obtained through this synergism are better than those obtained through the performance of each area. Furthermore, Yunus [2008] also stated that the first strategy to formulate a spatial synergism is an agreement on the vision of the synergism itself. The next strategy is formulating the missions to achieve the previously decided vision. The areas participating in this spatial synergism must have a strong commitment to conduct the interregional cooperation and to implement the formulated missions consistently and consequently.

As for the areas around the university that are part of the outskirts of Yogyakarta City, the spatial synergism can be in the form of interregional economic zone that is developed by areas on the outskirts that have different production factors. This factor difference may create a complementarity that promotes trade and investment. The geographical proximity is the key factor in minimizing transportation cost.

In a wider constellation, the outskirts of Yogyakarta City are part of the Special Region of Yogyakarta. Muta'ali [1998] stated that the regional development of areas experiencing the indications of urban sprawl consists of three main entities, namely economic, geographic, and political aspects. This finding is in line with Tacoli [2003].

The aim of the spatial synergism of the outskirts, including the areas around the university, is to improve trade and investment, create employment, establish interregional relationship between the more developed and the less developed areas, and, finally, improve the welfare of the society in every area. Furthermore, Rondinelli [1979] stated that this spatial synergism can be conducted by developing a production network, product distribution, and product exchange between the areas joining in this spatial synergism.

The outskirts of Yogyakarta City are part of the Special Region of Yogyakarta. The findings of this research show that the Special Region of Yogyakarta has interregional cooperation called Kartamantul (Yogyakarta-Sleman-Bantul). Kartamantul agreed on various sectors that are managed integratedly between the Governments of Yogyakarta City, Sleman Regency, and Bantul Regency, namely clean water, litter, waste, road infrastructure, and basic settlement infrastructure. The monthly coordination between the responsible institutions in these three administrative units aims to decide the development management of the five aforementioned sectors. This cooperation shows that the stakeholders perceive a spatial cooperation as necessary in improving the positive impacts and, at the same time, reducing the negative impacts of urban sprawl that emerging on the outskirts of Yogyakarta City, including the areas around the university. In term of regional constellation, the outskirts of Yogyakarta City also have an interregional cooperation that promotes spatial synergism. This phenomenon is in line with the visions and ideals of several stakeholders. Every stakeholder agrees that any forms of cooperation like Kartamantul require further improvement until they achieve their goals, provide more benefits, and, consequently, result in positive consequences to areas around the university that have been presenting the indications of urban sprawl.

\section{Assistance to Native People and Migrants}

The stakeholders concern on the negative impacts of urban sprawl that potentially emerge in areas around the university. One of the negative impacts is the behavioral change from rural to urban nature, which is not in accordance with the local culture and custome. For esample, urban consumptive behavior and extravagant lifestyle start to infiltrate the life of the native people.

When the areas around the university become the destination of migrant influx, various negative behaviors start to emerge in the life of the native people. The stakeholders proposed the implementation of assistance from responsible parties in order to reduce this negative impact. The following interview explains the need of assistance to the native people and the migrants.

"Well, some of the young people in this area follow the lifestyle of the university students, for example, they ask their parents to buy them nice motorcyles and mobile phones. If the parents are rich, then there will be no problem. But, what about the lowincome parents? Therefore, governmental assistance becomes necessary. The migrants, especially the university students who stay in the boards and lodgings, also require assistance so that they don't cause problems in the future." (Interview to E1/ informant from enterpreneurs on August 19, 2016)

This interview shows that the native people and the migrants need assistance to understand either the positive or the negative impacts of urban sprawl. This understanding potentially leads to the improvement of the positive impacts and the reduction of the negative impacts of urban sprawl. For example, the native people require an assistance that promotes their capabilities in dealing with the indications of urban sprawl occurring in areas around the university. In relation to capability improvement, Sarwadi et al [2013] found that there are two clusters of native households in Kasihan District, Bantul Regency, namely (1) native households that have the capability to create an opportunity out of urban sprawl and (2) native households that are marginalized. As for native households with ability to create opportunities, they will use their assets for concumption or production activities, commonly termed as 
'functioning.' 'Functioning' exists only when a person has the relevant capability, access to commodities/capitals/ resources, and supporting situation. Furthermore, Sarwadi et al [2013] explained that proprietary rights or access entitlements to various assets increase the capabilities and, thereby, widely open the opportunities for a person to 'function'. Households that have these opportunities will be able to improve their well-being.

Therefore, assistance is expected to prevent the native households from being marginalized. These households will be assisted until they have more capabilities to optimally take the economic opportunities created by the urban sprawl occurring in areas around the university. Finally, these housholds are expected to be able to improve their well-being.

\section{University-Village Integration}

This research found the importance of integration between the university and the village as a form of solution in improving the positive consequences and reducing the negative consequences of the emerging urban sprawl in areas around the university in Tamantirto Village. The following interview explains the importance of university-village integration. "The university and the village need to interact. There has to be a policy that integrates the university and the village. They have to 'live' side-by-side properly." (Interview to A1/informant from academics on August 11, 2016)

"I was asked several times by the people from UMY to deal with this problem. I proposed to UMY to also show their responsibility of addressing the problems occurring in the village, whih are caused by their university students. However, there is no response to this proposal. I always propose the same idea. Every time a discussion occurs, I always propose the same thing because there is no followup from UMY until now." (Interview to G3/informat from government agencies, on August 3, 2016).

These interviews describe that the stakeholders expect a policy that integrates the life of the university and the village as well. This policy is expected to create a harmonious living and a symbiotic mutualism between the university and the village. During the interview, one of the stakeholders explained as follows. "It is improper when a university does not provide student apartments because [the number of required temporary residence for the university residence] will reduce the existing space. Therefore, student apartments have to be directed to/managed by the society to improve their economy. It is a win-win solution for both the university and the village." (Interview to G5/informant from government agencies, on August 11, 2016)

Theintegration between the universityand the village will bring mutual benefits to every party. Consequently, a conflict between these two parties can be prevented. These findings are in line with Sarwadi et al [2013].

\section{Conclusion}

In order to improve the positive impacts and, at the same time, reduce the negative impacts of urban sprawl that emerges in areas around UMY, the stakeholders propose the following management strategies: (1) consistency in implementing spatial planning regulation, (2) spatial synergism in development planning, implementation, and monitoring, (3) assistance to the native people and the migrants, and (4) integration between the university and the village. Consistency in implementing spatial planning regulation becomes necessary especially in protecting productive and technically irrigated agricultural land for food security. Spatial synergism in development planning, implementation, and monitoring is important considering the indications of urban sprawl that emerge in one area area are related to other areas as well as to a wider regional constellation. Assistance to the native people and the migrants aims to prepare them to be able to wisely response to and create opportunities from urban sprawl. Universityvillage integration becomes necessary for living sideby-side harmoniously and for complementing each other so that a symbiotic mutualism is achieved.

\section{Acknowledgement}

Author would like to express her gratitude to the Graduate School of UGM for providing research funding through the scheme of Competitive GraduateSchool Lecturer Research Grant in 2016. Author would also like to thank Prof. Ir. Suryo Purwono, MA., Ph.D. and Dr. Tri Kuntoro Priambodo, M.Sc, as reviewers, for their significant inputs in improving this article.

\section{References}

Anjarsariningtyas, R., Laksmiasri, W., Pratiwi, A.A., dan Giyarsih,S.R. (2016). Food Security in Urban Sprwal Effected Area : Case Study in Sub Districts on The Outskirts of Yogyakarta City. Proceeding of The 13th International Asian Urbanization Conference, January 6-8, 2016. Hal 713-718

Brookfield., Hadi, S., dan Mahmud. (1991). The City in The Village : The in situ Urbanization of Villages, Villagers and Their Land Around Kuala Lumpur Malaysia. Oxford University Press. New York.

Dadi, D.,H. Azadi., F. Serbeta., K. Abebe., F. Taheri., T. Stellmacher. (2016). Urban Sprawl and Its Impacts on Land Use Change in Central Ethiopia. Urban Forestry and Urban Greening 16: 132-141

Dupras, J.J. Marull, L. Pancerisas, F. Coll, A. Ganzalez. (2016). The Impact of Urban Sprawl on Ecological Connectivity in the Montreal Metropolitan Region. Environmental Science and Policy 58: 61-73

Ewing, R., S. Hamidi., J.B. Grace., Y.D. Wei. (2017). Does Urban Sprawl Hold Down Upward Mobility? Lanscape and Urban Planning 48 : 80-88 Giyarsih, S.R. (2010). Urban Sprawl of The City of Yogyakarta, Special Reference to The Stage of Spatial Transformation. Indonesian Journal of Geography, Vol 42(1), 49-60. Giyarsih, S.R . (2012). Dampak Transformasi Wilayah Terhadap Kondisi Kultural Penduduk (Tinjauan 
Perspektif Geografis). Forum Geografi Vol 26(2),120-131.

Giyasih, S.R.. (2014). The Role of Yogyakarta and Surakarta Cities in the Intensity of the Regional Transformation of Two Villages Located in the YogyakartaSurakarta Corridor. Romanian Review of Regional Studies. Vol X, Number 1, 2014, halaman 15-22.

Giyarsih, S.R., dan Alfana, M.A.F. (2013). The Role of Urban Area As The Determinant Factor of Population Growth. Indonesian Journal of Geography Vol 45(1), 38-47.

Harini, R. (2012). Kajian Spasial Valuasi Ekonomi Lahan Pertanian Terkonversi dan Dampaknya Terhadap Produksi Pangan di Kabupaten Sleman. Disertasi. Fakultas Geografi UGM. Yogyakarta. Tidak Dipublikasikan.

Harini, R., Giyarsih, S.R., Ariani, R.D., dan Darusasi, R. (2014). Community Adaptation Model of Food Security Due to Global Warming in Kulon Progo. Proceeding of The 6th International Garduate Students and Scholars'Conference in Indonesia, November 19 th and 20th ,2014 halaman 305-320.

Kiggundu, A.T. (2014). Constrains to Urban Planning and Management to Secondary Town in Uganda. Indonesian Journal of Geography 46(1) : 12-21

Moleong, L.J. 2005. Metodologi Penelitian Kualitatif. Jakarta. Proyek Pengembangan LPTK.

Morote, A.F., M. Hernandez. (2016). Urban Sprawl and Its Efeects on Water Demand : A Case Study of Alicante, Spain. Land Use Policy 50 : 352-362

Mutaali, L. (1998). Tinjauan Geografis Segitiga Pertumbuhan Dalam Pembangunan Wilayah. Paper disampaikam dalam diskusi bulanan di Jurusan PPW Fakultas Geografi UGM tanggal 23April 1998.

Nazarnia, N., C. Schwick., J.A.G., Jaeger. (2016). Accelerated Urban Sprawl in Montreal, Quebec city and Zurich: Investigating the Differences Using Time Series 1951-2011. Ecological Indicators 60 : 1229-1251

Osman, T., T. Arima., P. Divigalpitiya. (2016). Measuring Urban Sprawl Patterns in Greater Cairo Metropolitan Region. Journal of Indian Social Remote Sensing 44 (2) : 287-295

Oueslati. W., S. Alvanides, G.Garrod. (2015). Determinants of Urban Sprawl in European Cities. Urban Studies 52 (9) : 1594-1614

Pemda Kabupaten Bantul. (2011). Perda No 04 Tahun 2011 tentang Rencana Tata Ruang Wilayah Kabupaten Bantul Tahun 2010-2030 di Yogyakarta

Rachmawati, R.Junaedi, A., Rijanta. (2004). Peran Kampus sebagai Pemicu Urbanisasi Spasial di Pinggiran Kota Yogyakarta. Majalah Geografi Indonesia.18 (1) :45-56

Rondinelli, D.A. (1979). Spatial Factors in Resources System : Spatial Analysis for Integrated Regional Development Planning in the Bicol River Basin of the Philipines, UN University and Chung Ang University. Seoul Korea.

Sarwadi, A., Giyarsih, S.R., Pramono, R.W.D. (2013). Penguatan Kapabilitas Masyarakat Pinggiran Kota, Studi Kasus Kecamatan Kasihan, Kabupaten Bantul Daerah Istimewa Yogyakarta. Laporan Penelitian. Pusat Studi Perencanaan Pembangunan Regional UGM (Tidak dipublikasikan).

Setyono, J.S. Yunus, H.S., Giyarsih, S.R. (2016). Spatial Pattern of Urbanization and Small Cities Development in Central Java : A Case Study of Semarang-Yogyakarta-Surakarta Region. Journal of Geomatic and Planning. Vol 3(1), page 53-66

Shatkin, G. (2016). The Real Estate Turn in Policy and Planning : Land Monetization and the Political Economy of Peri-Urbanization in Asia. Cities $53: 141-149$ Skog, K.L., M. Stelnnes. (2016). How Do Centrality,
Population Growth and Urban Sprawl Impact Farmland Conversion in Norway. Land Use Policy 59 : 185-196 Sriartha, I. P.,and Giyarsih, S.R. (2015). Spatial Zonation Model of Local Irrigation System Sustainability (A Case of Subak System in Bali). Indonesian Journal of Geography, Vol47(2), 42-150

Subroto, Y.W., dan Setyadi. (1997). Proses Transformasi Spasial dan Sosio Kultural Desa-Desa di Daerah Pinggiran Kota (Urban Fringe) di Indonesia (Studi Kasus Yogyakarta). Laporan Penelitian Ilmu Pengetahuan Dasar. Yogyakarta. Pusat Studi Lingkungan Universitas Gadjah Mada. Yogyakarta. (Tidak dipublikasikan) Surya, B. (2016). Change Phenomena of Spatial Physical in the Dynamics of Development in Urban Fringe Area. Indonesan Journal of Geography 48 (2) : 118-134

Sudarajat.(2016). Farmers CommitmentinMaintainingWetted Land Ownership Status in Peri Urban Area of Yogyakarta. Indonesian Journal of Geography 48 (1) : 91-101

Sudarajat. (2013). Tinjauan Spasial Komitmen Petani Mempertahankan Kepemilikan Lahan Sawah dan Pemanfaatannya Untuk Lahan Pertanian di Kabupaten Sleman dan Kabupaten Bantul. Disertasi. Fakultas Geografi UGM. Yogyakarta. Tidak Dipublikasikan.

Sugiyono. (2007). Metode Penelitian Pendidikan. Bandung. Alfabeta.

Sutaryono. (2012). Marginalisasi Petani di Daerah Istimewa Yogyakarta. Tesis. Fakultas Geografi UGM (Tidak dipublikasikan). Tacoli, C. (2003). The Links Between Urban and Rural Development. Environment and Urbanization Vol 15 (1) 3-12.

Tian, L., B. Ge., Y. Li. (2017). Impact of State-Led and Bottom Up Urbanization Land Use Change in the Peri-Urban Areas of Shanghai : Planned Growth on Unconntrolled Sprawl?. Cities 60 :476-486

Wei, F., and P. L. Knox. (2015). Spatial Transformation on Metropolitan Cities. Environmental and Planing A 47 : 50-68

Weilermann, B., I. Seidl., T. Sculz. (2017). The Socio Economic Determinants of Urban Sprawl Between 1980 and 2010 in Switzerland. Landscape and Urban Planning 175: 468-482

Winarso, H., D. Hudalah, T. Firman. (2015). Peri Urban Transformation in the Jakarta Metropolitan Area. Habitat International 49 : 221-229 Woltjer, J. (2014). A Global Review of PeriUrban Development and Planning. Journal of Regional and City Planning 25(1): 1-16 Yunus,H.S. (2008). Dinamika Wilayah Peri Urban, Determinan Masa Depan Kota. Pustaka Pelajar. Yogyakarta. 